\title{
Repairing China's Power Grid Amidst Perpetual Warfare, 1937-1955
}

\author{
Ying Jia Tan
}

When Harbin, a city under Communist control, was plunged into darkness in September 1946, a motley crew of electricians came to its rescue and thwarted the attempts by the Nationalist regime to retake the city. ${ }^{1}$ Chiang Kai-shek's Nationalist regime and Mao Zedong's Communist Party had turned against each other shortly after the Japanese surrender in August 1945. Northeast China, which was under Japanese control between 1932 and 1945 as the puppet state Manchukuo, became a key battleground for the Civil War. After the Soviet Red Army withdrew in March 1946, the Communists moved in to fill the power vacuum. Driven by irredentism and a desire to control industrial resources, the $\mathrm{Na}$ tionalists deployed troops to retake the Northeast from the Communists. ${ }^{2}$ They fired the first salvo by cutting off electrical power from the Fengman Hydroelectric Dam to Harbin. The Communists responded by mobilising workers to overhaul disused generators and restored the city's electrical power supply.

Liu Yingyuan, the worker who purportedly took charge of the repairs, became recognised as a "model labourer". He moved to the Northeast when he was eleven years old, where he started out as a packer for the British-American Tobacco Company and worked many odd jobs before becoming an apprentice in a machine shop. ${ }^{3}$ Liu's contribution to the rehabilitation of Harbin's power infra-

1 Guanying: "Haerbin fadianchang [Harbin Power Plant]", in: Renmin ribao, 1 May 1948, p. 2.

2 For an authoritative account of the Chinese Civil War, see Westad, Odd Arne: Decisive Encounters, Stanford: Stanford University Press 2003.

3 Anon.: "Zhongguo gongren de guangrong - ji gongren chushen de changzhang Liu Yingyuan [The glory of China's workers - Remembering Liu Yingyuan, the worker who became factory director]", in: Renmin dianye 4 (Jan. 1951), p. 7-11. 
structure was immortalised in the 1947 propaganda film Minzhu dongbei (Democratic Northeast). Speaking to reporters in 1948, the director of Harbin Power Station Xiao Changhai hailed Liu as a "labour hero", who "miraculously repaired the blades on the generators". He pointed out that when the generator broke down during the Manchukuo era, it had to be airlifted to Dalian and shipped to the Mitsubishi factory in Japan for repairs. Liu apparently completed the repairs in 28 days, all the while being "ridiculed by certain backward elements". Xiao completed his account by bringing up the heroic image from the movie of Liu flexing his muscular arms as he grasped the wrench and said, "[i]n the end, he made the untamed metal beast growl and spin obediently". "After distinguished service at Harbin, Liu was appointed deputy director of the power stations in Changchun and Fushun and restored power to these two Northeastern cities that suffered massive casualties during the Civil War. When the Communists came to power in 1949, Liu was transferred to Beijing, where he served as director of Shijingshan Power Station, which supplied most of the electricity for the new nation's capital. ${ }^{5}$

Liu was one of thousands of electrical workers and engineers swept up in the crossfire during the age of "perpetual warfare" between 1931 and $1955{ }^{6} \mathrm{He}$ nonetheless remained far from the front lines of the war between China and Japan from 1937 to 1945 and only came face-to-face with armed conflict after the Soviet invasion of Manchuria in August 1945. In comparison, China's first gen-

4 Guanying, "Haerbin fadianchang".

5 Anon.: "Zhongguo gongren de guangrong", p. 8.

6 The Mukden Incident of 18 September 1931 marked the beginning of armed conflict between China and Japan. The Japanese Kwantung Army orchestrated a railway bombing near Mukden (now Shenyang, Liaoning Province) and used it as a pretext to invade Northeast China. They established the client state of Manchukuo. This was quickly followed by the 1932 Battle of Shanghai, during which Shanghai became the first city to experience an air raid. On 7 July 1937, a minor skirmish escalated into the all-out Japanese invasion of China. The War of Anti-Japanese Resistance lasted until August 1945. Soon after, China descended into civil war, which led to the Communist takeover of mainland China and Nationalist retreat to Taiwan. The state of war continued even after the founding of the People's Republic of China in October 1949. This was followed by the mobilisation for the Korean War between 1950 and 1953. Although the military administration came to an end in 1953, the Chinese Communist Party continued to pursue a number of mass mobilisation campaigns that led to the militarisation of civilian life. 
eration of "engineer-bureaucrats" devoted themselves to revolutionary causes and war for their entire careers. ${ }^{7}$

This was the case for Bao Guobao, an engineer who played an integral role in developing China's electrical industries under both the Nationalist and Communist regimes. Born in Zhongshan county in Guangdong, which happened to be the home town of the founding father of the Chinese Republic, he attended the secondary school affiliated with Jiaotong University and Tsinghua College before obtaining a Bachelor's degree in Mechanical Engineering from Cornell University in Ithaca, New York in 1922. After graduating, he taught at Zhejiang University and Jiaotong University and worked at a cotton textile mill in Zhengzhou, in Henan Province. In 1928, Bao abandoned his career in the private sector to join the National Construction Commission, an agency of the executive branch of the Nationalist government that managed state-owned power companies and regulated the private power sector across the nation. Bao oversaw the nationalisation of Nanjing Power Company in 1929. He was later appointed chief engineer of the power companies in Fuzhou and Guangzhou and reorganised their operations. ${ }^{8}$ As will be shown later, before the war, Bao focused his efforts on replacing obsolete equipment and paid little attention to repair. After the Japanese invasion in July 1937, he began coordinating repair operations that served strategic military goals, which contributed to the accumulation of repair knowledge. Bao transferred his engineering expertise to the Communist Party when he defected after the Communist capture of Beiping (later renamed Beijing).

Drawing on published sources such as engineering journals and newspapers, this article examines how the age of perpetual warfare between 1931 and 1955 shaped the major shifts in repair culture within China's electrical industries. Before the Second Sino-Japanese War (1937-1945, in China most commonly known as the War of Anti-Japanese Resistance) in July 1937, system builders were preoccupied with replacement and not repair - a lack of expertise in repair meant that it was easier to replace faulty components. Cut off from foreign supplies after the fall of the coastal cities to Japan, Chinese engineers who retreated to Southwest China built and repaired power systems that were often blown up

7 This term refers to engineers employed by the government. I have chosen to refer to them as "engineer-bureaucrats" as it reflects their primary identity as members of a rationalistic bureaucracy who executed the government's policies. Their roles as engineers were secondary to their bureaucratic functions.

8 Bao, Guobao: Human resource file, 15 Oct. 1946, Aide-de-camp intelligence records, 12900000097A, Academia Historica, New Taipei City, Taiwan. 
by the enemy. They scraped together any electrical equipment they could find, refurbished damaged equipment and accumulated expertise in manufacturing equipment and parts on their own through these acts of repair. "Broken world thinking", to borrow Steven Jackson's idea, was not merely a philosophical exercise for China's first generation of engineers but a normal state of affairs, as "erosion, breakdown and decay" marked the "starting points" of China's electrical industry. ${ }^{9}$

The Civil War (1946-1949) and the early years of the People's Republic (1949-1955) marked another turning point, which saw rank-and-file workers lay claim to the narrative of heroic repair, thereby challenging the expertise of highly educated engineers. Most of the engineers who built and maintained the power infrastructure during the Anti-Japanese War of Resistance defected to the Communists after 1949. They facilitated the transfer of knowledge across different political regimes and the codification of maintenance and repair protocol. China's first generation of electrical engineers was well aware of the inherent defects built into the power infrastructure. Power bureaus, which came under immense pressure to increase power output without installing new generators, assumed the risk of catastrophic failure by running these faulty systems close to maximum capacity. Engineers and workers addressed systematic failures with conflicting approaches. Workers chose to tinker, but engineers attempted to formalise maintenance procedures. In the end, workers came to dominate repair culture, as their actions fitted with the Communist ideology of workers seizing the means of production.

\section{INHERITING A BROKEN WORLD}

When the Nationalist government under Chiang Kai-shek established its new capital in Nanjing in 1928 after brokering peace with various warlord regimes, it inherited a broken world torn apart by years of ceaseless warfare and political turmoil. The founding father of the Chinese Republic, Sun Yat-sen, saw the construction of a national capital that was clean, efficient and offered the newest technology as the first step to achieving "national, political, and ideological uni-

9 Jackson, Steven J.: "Rethinking Repair", in: Gillespie, Tarleton/Boczkowski, Pablo J./ Foot, Kirsten A. (eds.): Media Technologies: Essays on Communication, Materiality, and Society, Cambridge, MA: MIT Press 2014, p. 221-239. 
ty" ${ }^{10}$ Sun died in 1925 before achieving his revolutionary goals. China's electrical industries reflected the economic reality confronting the new national government. There were 704 power stations across China, 523 of which were owned by Chinese businessmen. The average installed capacity was $394 \mathrm{~kW}$, barely enough to power street lights in a small county seat and a few workshops. With average capitalisation at $\$ 105,491$, these small private power plants lacked the capital to expand. Foreign capitalists dominated China's electrical power sector, as their installed capacity of $273,262 \mathrm{~kW}$ exceeded that of Chinese-owned power stations. There was also no national electrical power standard to speak of. Some $81.6 \%$ of China's power companies adopted a mains voltage of 220/380 V and $50 \mathrm{~Hz}$ in 1930, with the rest adopting $110 \mathrm{~V}$ and $60 \mathrm{~Hz} .{ }^{11}$ Fragmented and undercapitalised, these small power stations struggled to remain in business.

Nanjing's electrical infrastructure was hardly befitting for a national capital. Neglect of routine maintenance and failure to collect unpaid electricity bills caused the new capital's power company to be broken beyond repair. The Nanjing Power Company had two power stations - one in Xiaguan equipped with a $1,000 \mathrm{~kW}$ generator, and the other at Xihua Gate in the western part of the city with six steam engines, an apparent power rating of $840 \mathrm{kVA}$ and a real power rating of $300 \mathrm{~kW}$. In his report based on a January 1928 survey, former Nanjing engineer Shen Sifang admitted that "the boiler suffered from excessive corrosion, causing a thick layer of sediment to form in the boiler, thus reducing its efficiency". ${ }^{12}$ The generator at Xihua Gate only achieved an output voltage of $1,500 \mathrm{~V}$, which was half of its 3,300 V setting. Every night, it burned 29 tons of coal to generate $4,000 \mathrm{kWh}(7.25 \mathrm{~kg}$ of coal per $\mathrm{kWh})$. The rotor blades on the General Electric generator at Xiaguan Power Station were damaged. It generated $8,000 \mathrm{kWh}$ by burning 29 tons of coal nightly, but this fuel consumption rate was still much higher than the $1 \mathrm{~kg}$ of coal per $\mathrm{kWh}$ benchmark. $60 \%$ of the electricity was lost through splicing. Although the mains voltage was $220 \mathrm{~V}$, the actual voltage reading was as low as 30 to $40 \mathrm{~V} .{ }^{13}$ The power system in Nanjing needed a massive overhaul.

10 Musgrove, Charles: "Building a Dream: Constructing a National Capital in Nanjing, 1927-1937”, in: Esherick, Joseph (ed.): Remaking the Chinese City: Modernity and National Identity, 1900 to 1950, Honolulu: University of Hawaii Press 2002, p. 139-158.

11 World Power Conference: Transactions Third World Power Conference vol. 1, Washington DC: Government Printing Office 1936, p. 117.

12 Shen, Sifang: "Zhengli shoudu dianchang gongzuo zhi yiduan [Anomalies observed in the retrofitting of Capital Power Station]", in: Gongcheng 4:2 (1929), p. 266-268.

13 Bao, Guobao: "Shoudu dianchang zhi zhengli ji kuochong [The retrofitting and expansion of the Capital Power Station]”, in: Gongcheng 4:2 (1929), p. 269-271. 
The replacement of obsolete generators was preferred over repair, as it delivered the desired results quickly. Bao Guobao, who assumed responsibility for the nationalisation of China's electrical industries as director of the electrical power division in the National Construction Commission, installed two small diesel generators with a generating capacity of $137 \mathrm{~kW}$ as a stop-gap measure. He had three reasons for doing so. One, diesel generators could be activated upon installation and offered instantaneous relief for power shortages. Two, they did not require much water, which was important since the power station was a distance away from the river. Three, they could be used as back-up power after the installation of a boiler and turbines purchased from Worthington Pump \& Machinery and the Brown-Boveri Group. He also outlined plans to demarcate the service areas of both power stations to better monitor transmission voltage. ${ }^{14}$ He offered few details on maintenance tasks such as boiler repairs and wire pole replacement; it was not that they were unimportant but they did little to resolve fundamental problems in Nanjing's power infrastructure.

Bao drew on his experience of rehabilitating Nanjing's power network when he took charge of industrial regulation and argued that the most effective way to lower costs was the replacement of obsolete equipment. Bao illustrated his point with this example: A new $1,000 \mathrm{~kW}$ generator, which burned 4 pounds of coal for every $\mathrm{kWh}$, cost 150,000 silver dollars. The annual cost saving in coal was 57,000 silver dollars, which meant that the power company could recover the cost of the generator with three years of fuel savings. ${ }^{15}$ For Bao, the equipment's age was not the determining factor of obsolescence. In deciding whether to replace their capital assets, power companies needed to carry out cost-benefit analyses based on comparisons with available technology.

Industrial regulation became a means to mend the "broken world" resulting from decades of mismanagement. Bao pointed out that most power companies experienced a line loss of more than $50 \%$, which he attributed to mistakes in network design made by untrained craftsmen. Bao castigated power companies for neglecting routine inspection and condoning the theft of electrical power. He requested that private power companies submit the drawings of generators and grid layout during registration for approval. This would allow regulators to identify potential design flaws and overlapping service areas. ${ }^{16}$

14 Ibid.

15 Bao, Guobao: "Banli dianqi shiye zhe ying you zhi zhuyi [On the management of the electrical industries]”, in: Dianye jikan 1:1 (1930), p. 1-5.

16 Ibid. 
Private power plant operators shared Bao's concerns but saw the establishment of an electrical equipment industry as the fundamental solution to the inefficiencies of China's electrical industries. Sun Shihua, a co-founder of the Association of Private Chinese Electric Corporations, expressed his frustration with the haphazard acquisition process of Chinese power plants. Power companies lacked the capital to replace obsolete equipment. Sun noted that as a result, "old power plants were littered with abandoned machines and looked like cabinets of curiosities". Furthermore, the Chinese not only relied on imported electrical equipment but also depended on foreign suppliers for repair and maintenance. ${ }^{17}$ Returning to Liu Yingyuan's anecdote in the introduction, the Japanese-built power company in Manchukuo had to ship the generator back to Japan for repairs when it broke down.

Chinese power plant owners cited Japan's experience to show how electrical equipment manufacturing contributed to the accumulation of repair and maintenance expertise. Sun pointed to the rapid expansion of the Tokyo Electric Company, which started operations in 1887 with a $25 \mathrm{~kW}$ DC generator and increased its total installed capacity to 2.23 million $\mathrm{kW}$ in 1925 . Sun attributed its exponential growth to the emergence of a vibrant electrical equipment industry during the First World War. He estimated that dozens of Japanese electrical equipment firms held $\$ 400$ million of capital and had an annual output worth \$200 million. The electrical equipment industry was a foundational enterprise that offered vocational training to thousands of workers and also provided many opportunities for technical transfer through joint ventures with foreign firms. Sun himself had completed an apprenticeship in a wire manufacturing plant at General Electric in 1915, where he had learned how to work with metal and insulating materials. When he returned to China to work for the Foochow Power Company, Sun organised training sessions for ten workers, which "equipped workers with the expertise to make and repair meters, fans, motors and transformers on their own". Small-scale efforts by a local power company had a limited impact. ${ }^{18}$ Until 1938, China's electrical industries primarily relied on imported equipment and lacked the technical expertise to conduct basic repairs.

17 Sun, Shihua: "Guoren ji yi chuangshe dianqi zhizao gongye [The people of our nation should quickly establish an electrical equipment manufacturing industry]", in: Dianye jikan 1:1 (1930), p. 7-11. Quotation from p. 8.

18 Ibid. 


\section{LEARNING TO REPAIR AT WAR}

Sun's vision for a domestic electrical equipment industry came to fruition soon after the Japanese invasion. Plans to manufacture electrical components and military communication devices began as early as 1935 . When the war against Japan broke out in July 1937, coastal cities fell under Japanese control, cutting off vital imports of raw materials and machinery. The National Resources Commission, an agency in charge of wartime industrialisation, coordinated the evacuation of China's industries inland. It had initially planned to situate the wartime industries in Xiangtan, in Hunan Province, in the Middle Yangtze region. The Japanese carried out a massacre in the Nationalist capital Nanjing in December 1937 and marched up the Yangtze River to capture the interim wartime capital in Wuhan in October 1938. The Resources Commission uprooted the industries and evacuated further inland. The engineer-bureaucrats dismantled boilers and turbines and had them transported on boats and mule carts through hundreds of miles of river valleys and mountain tracks into the mountainous southwestern provinces of Sichuan, Yunnan and Guizhou. ${ }^{19}$ Against all odds, the Resources Commission had established a power station, copper smelting plant and electrical equipment manufacturing industry by 1939 in Yunnan's provincial capital Kunming, which would become the backbone of the wartime industrial complex. In 1938, Bao fled from Nanjing to Sichuan, where he stayed until 1944, using salvaged and refurbished components to build two power stations in Sichuan under the looming threat of Japanese air raids.

As well as restoring power supply to sustain China's war machine, repair work provided an avenue for engineers and workers to learn how to manufacture electrical equipment without foreign assistance. The Resources Commission established manufacturing facilities for wires, radio tubes and field telephones through technology transfer agreements hastily completed before 1937. As the supply of raw materials slowed to a trickle, laboratories at the electrical equipment plant developed alternative materials to relieve the shortage of spare parts. Japanese control over French Indochina after September 1940 exacerbated the problem, as it was no longer possible to transport heavy machinery through the railways between the port city of Haiphong and Kunming. ${ }^{20}$ The Chinese now had to build generators on their own.

19 Tan, Ying Jia: Recharging China in War and Revolution, Ithaca: Cornell University Press 2021, p. 80-82.

20 Ibid., p. 96. 
The retrofitting of a damaged generator for the Longxi River Hydropower Plant just outside the wartime capital in 1942 reveals how wartime scarcity compelled the engineer-bureaucrats to build a self-reliant industry. Zhang Chenghu, the engineer who had completed the technology transfer agreement with a British wire manufacturer, detailed the refurbishment that was completed with domestically-made components and designs drafted by Chinese engineers:

"The Longxihe Hydroelectric Plant run by the National Resources Commission purchased a $2500 \mathrm{~kW}(600 \mathrm{rpm})$ generator. The steel sheet stator was deformed and the generator coils were completely destroyed. It appointed the Electrical Works to repair and modify it into a $1700 \mathrm{~kW}, 6900 \mathrm{~V}$ generator, to suit the needs of the Changshou Hydroelectric Facility. Our plant took charge of the redesign, manufactured the generator coils on our own, used mica insulating material and completed the project in a year. Apart from handing the production and installation of the steel stator to the Minsheng Machine Works in Chongqing, we designed and installed every other component. The generator has been in use for nearly a year, and we have not heard of any malfunction. It is truly an accomplishment for the domestic electrical industries to complete the retrofitting of high-voltage and highcapacity power generators." 21

The completion of the Longxi River hydropower project was a milestone for China's electrical industry. Prior to this, China's electrical equipment industry had depended on imported raw materials and made products by copying foreign designs. Years of dismantling, reassembling and repairing electrical equipment on the run had equipped the engineers with much-needed expertise to handle various types of electrical components. ${ }^{22}$ After completing the Longxi River project, the Electrical Manufacturing Works conducted similar repairs for the damaged hydropower turbines at Yaolong Hydropower Station in Yunnan and Xiuwen Hydropower Station in Guizhou in 1943. It also applied the experience from refurbishing the hydropower generator for Longxi River to manufacture a $220 \mathrm{hp} / 750 \mathrm{rpm}$ hydropower turbine for the Wanxian Hydropower Station in Sichuan in $1944 .^{23}$

21 Zhang, Chenghu: "Guoying dianli jiqi shiye zhi chengzhang yu zhanwang [The growth and outlook for state-owned electrical machine industry]", in: Ziyuan weiyuanhui jikan 5:2 (1945), p. 214. Also cited in Tan, Recharging China, p. 101-102.

22 Yun, Zhen: "Wunian lai Zhongguo dianji zhizao zhi jinbu [Improvements in electrical equipment manufacturing]", in: Diangong 1 (1943), p. 8-12.

23 Ibid, p. 11. 
The electrical industry that came of age during the War of Resistance against Japan was soon caught in the crossfire of the civil war between the Nationalists and the Communists. Instead of building on their earlier achievements, engineers and workers spent most of their efforts protecting the electrical infrastructure from enemy destruction. The Communists glorified the repair work completed by rank-and-file workers. Stories of heroic repair not only proved that the workers supported the revolutionary cause of the Communists; they also showed the Communists to be competent urban administrators.

Maintenance, or the lack thereof, was a central theme of the anecdote in the opening paragraphs about Liu Yingyuan's "heroic" repairs during the Nationalist assault on Harbin in the fall of 1946. The coal-fired power plant in Harbin had fallen into disuse, so Harbin came to depend on the Fengman Hydropower Station about $252 \mathrm{~km}$ south of the city after 1943. In their attempt to dislodge the Communists from Harbin, Nationalist forces cut off electricity from the Fengman plant and plunged the city into darkness. The Communist newspaper People's Daily reported that the workers responded by working day and night to repair the disused generators and restored power one autumn evening. ${ }^{24}$ Liu Yingyuan received the "Hero of Labour" award for leading the repair efforts.

The article about Harbin Power Plant also tells an incredulous tale of Zhang Kexing, another "labour hero" who climbed into the boiler and braved the scorching heat to replace a 200-pound moulding brick. Zhang came to Harbin at age 17 and worked at the power station for 28 years, eventually being promoted to chief of the boiler repair section. Workers recounted Zhang's superhuman feat:

"During the era of the bogus Manchukuo regime, we would have to wait for three days for the boiler to cool down before working, which would lead to a three-day power outage ... Now the workers are taking charge of the factory. None of us are willing to idle the machines that make military supplies for our soldiers on the front line. Old Hero Zhang thought of a way to quickly fix the problem. He ordered workers to remove the burning coals for the boiler and lay out thick straw mats on the furnace. The workers wrapped themselves in thick clothing and burlap sacks before crawling into the furnace, while others sprayed water to cool them down from behind. Zhang and a few workers installed a 200-pound moulding brick under these conditions." 25

24 Guanying, "Haerbin fadianchang".

25 Ibid. 
Stories of heroic repairs publicised through Communist propaganda laid the groundwork for workers to seize control of the means of production. Mobilisation for war forced workers to conduct swift repairs, as was the case during the War of Anti-Japanese Resistance. The spirit of self-reliance was also carried over from the earlier period. The Civil War effected a cultural change among the electrical workers. The stories of Liu and Zhang highlighted the flaws of electrical power systems and practices inherited from the Japanese. These heroic figures marked a clean break from the past, as they rallied other workers to take the lead and adopt new maintenance and repair procedures. Electrical workers came to be seen as comrades-in-arms of the People's Liberation Army. The battlehardened engineers also threw in their lot with the Communists in the Civil War. After the founding of the People's Republic, maintenance and repair continued to be couched in militaristic language - a legacy of at least twelve years of ceaseless warfare.

\section{REPAIRING THE NATION}

The Civil War did not end with the proclamation of the founding of the People's Republic of China in October 1949. New China was quickly drawn into the Korean War in October 1950. As the electrical industry remained on a war footing, the Communists mobilised engineers and workers to guard against sabotage. The mobilisation of the masses broke down the top-down command structure of the electrical industries that had long been dominated by the educated engineering elite. The Communists created an institutional framework that welcomed input on the improvement of maintenance and repair practices from both engineers and workers. The electrical industries experienced their "let a hundred flowers bloom" moment in the 1950s, when engineers and workers proposed a vast array of ideas to improve the reliability of the power system. As we will see, workers focused on tinkering with the workflow to optimise output with limited resources. Engineers attempted to formalise maintenance procedures. This multifaceted approach to maintenance and repair allowed the Chinese to unleash the full potential of their existing capacity.

Workers and engineers offered differing maintenance and repair solutions to improve overall efficiency and reliability. Bao Guobao, the engineer who had developed the power infrastructure for the Nationalist government before and during the war, defected to the Communists in 1949 and was appointed as the director of the Electrical Power Division under the PRC's Ministry of Fuel Re- 
sources. ${ }^{26}$ Liu Yingyuan, the worker hero who purportedly saved Northeast China from darkness, took over as director of the Shijingshan Power Plant that supplied most of Beijing's electricity. ${ }^{27}$ While Bao worked at the ministerial level, Liu focused on the day-to-day operations of maintaining a stable power supply to the new capital. Bao, who had served as general manager of the state-owned North Hebei Electric Company between 1945 and 1949 under the Nationalist regime, knew the vulnerabilities of the North China power grid too well. Shijingshan Power Station had been built in the 1910s and changed hands between private Chinese businessmen, Japanese regional power companies and Nationalist engineer-bureaucrats over a period of nearly four decades. As every owner installed a new generator without getting rid of the old one, the crew had to maintain generators with five different voltage settings $(110,220,380,3,300$ and $5,200 \mathrm{~V})$. It was impossible to find spare parts for the largest generator, which was built by the Japanese by imitating Swiss designs. ${ }^{28}$ Between December 1948 and January 1949, Bao was trapped in Beiping during the siege on the city. The People's Liberation Army captured the power station moments before attacking the city. They intermittently cut off power to hundreds of thousands of inhabitants and troops, which led to the "peaceful liberation" of Beijing. ${ }^{29}$ The trauma of war was also fresh in Liu Yingyuan's mind. In the Northeast China battlefield, Liu witnessed how the PLA pounded the enemy into submission by cutting off electricity to the city. He experienced first-hand how difficult it was to restore power to war-torn cities.

The electrical infrastructure of the new capital was no more reliable than that of the old Nationalist capital. Within the first eight months of 1950, Beijing reported 48 deaths from electrocution, while Tianjin reported 31. Residents making illegal hook-ups to the power line and thieves stealing power cables to sell them as scrap metal accounted for some of the deaths. The North China Power Bureau took responsibility for some of these accidents. It concluded that the deaths were all preventable. If the power bureau had been more diligent with its routine maintenance, accidental contact with high-voltage lines would have been

26 Aide-de-camp: Personnel report on Bao Guobao, circa 1950, Aide-de-camp papers, 12900000097A, Academia Historica, Xindian District of New Taipei City.

27 Anon., "Zhongguo gongren de guangrong", p. 9.

$28 \mathrm{Xu}$, Ying: Dangdai Zhongguo shiye renwu zhi [Collective biography of industrialists in modern China], Shanghai: Wenhai chubanshe 1948, p. 191-202.

29 Id.: Beiping eryue weicheng ji [Two-month siege of Beiping], Beijing: Beijing chubanshe 1993. 
averted ${ }^{30}$ Between April and July 1950, Shijingshan Power Station reported 8 to 13 serious incidents, mostly resulting from generator malfunction. An inspection team rectified seven sets of problems, including poor connections within the rotor, improper insulation of ball-bearing tubes and accumulation of dirt in fan coils and switches, and reduced the number of serious incidents to two by $\mathrm{Au}-$ gust $1950 . .^{31}$

Incident reports from Shijingshan Power Plant suggest that these breakdowns resulted from the overuse of existing electrical equipment and the deferment of elective maintenance. As the Ministry of Fuel Resources pursued a policy of unleashing the full potential of existing equipment, power stations across the country operated at full capacity to increase output, which left little down time for inspection and routine maintenance. It was estimated that $28.5 \%$ of the existing generating capacity had been frozen as a result of years of disrepair, and that the power output could be increased by several hundred thousand $\mathrm{kW}$ simply by repairing broken equipment. ${ }^{32}$ Soviet advisers fuelled their expectations by endorsing this view. They even ridiculed their Chinese counterparts for curtailing power output out of fear of causing excessive wear and tear. China's electrical power sector did increase its output by $20 \%$ without installing new equipment, ${ }^{33}$ but this heightened the risk of catastrophic failure. The reduction of breakdowns reported in August 1950 proved to be illusory. Problems resurfaced at the Shijingshan Power Station within a few months. Technicians skipped a major repair in November 1950 because Shijingshan Power Plant had to make up the shortfall resulting from the overhaul of Tianjin Power Plant. The operators did not remove the stator for cleaning during the minor repair in January 1951. Three months later the stator burned out, as large amounts of dirt had clogged up the generators' vents, warping the wiring insulation. ${ }^{34}$

30 Anon.: "Anquan yongdian, bimian chudian shigu [Use electricity safely, avoid accidents]", in: Renmin dianye 2 (Oct. 1950), p. 90-97.

31 Shijingshan Power Station: "Jiancha xiaozu chubu chengji shouhuo baogao [Preliminary results of the inspection group]", in: Renmin dianye 2 (Oct. 1950), p. 17-20.

32 Zhongyang ranliao gongyebu [Ministry of Fuel Resources]: Dianye jihua jiangxi ban jiangyi, Beijing: Ranliao gongyebu chubanshe 1952, p. 343.

33 Anon.: "San nian li Sulian zhuanjia gei women de bangzhu he jinhou women ruhe geng hao de xiang Sulian xuexi [Assistance rendered by the Soviet Union in the past three years and how we should learn from the Soviets from now on]", in: Renmin dianye 22 (Dec. 1952), p. 2-3.

34 Anon.: "Duiyu Shijingshan fadianchang yici fasheng zhongyao shigu de jiancha zongjie, [Conclusion of inspections following multiple serious accidents at Shijingshan Power Station]", in: Renmin dianye (May 1951), p. 9-16. 
As a factory director who started out as a worker, Liu maximised power output by adjusting the workflow to improve the combustion rate of coal. When Liu won the model labourer award in September 1950, he was praised for "exterminating a huge enemy" by reducing the amount of pulverised coal that was escaping from the chimneys of Shijingshan Power Plant. Not only were workers contracting lung disease after inhaling coal dust; five to six tons of coal were escaping from the chimneys every day. The biographical essay claimed that many experts, including Soviet advisers, had attempted to solve the problem, but only Liu had set his mind to it. ${ }^{35}$ Liu resorted to offering of 20,000 jin of millet to any worker who fixed the problem. The workers implemented a joint suggestion from two workers and the Soviet advisers to patch up a ventilation gap in the coal pulveriser, but that only solved half of the problem. Two other workers modified the design of the coal conveyor to stabilise the feed and improve the burn rate. These modifications saved 2,000 tons of coal each year, which reduced the cost of power generation.

Workflow adjustments allowed Liu to identify safety lapses. On 5 June 1950 two workers overfilled the steam generators and caused water to seep into the turbine. Liu made an example of the negligent workers and highlighted the importance of "exterminating" accidents. He demoted the workers at fault and rewarded those who detected problems. His biographical sketch does not indicate whether he took any measures to rectify systematic mechanical faults causing generator breakdowns.

While workers tinkered with the workflow, engineers focused on identifying weak links accumulated as a result of the rapid succession of regime changes. A Japanese-made generator installed during the war accounted for most of the breakdowns. It was jointly manufactured by Hitachi and Mitsubishi in the 1940s based on imitations of AEG's products, but the windings for the rotors were made with thinner material and inadequately stretched, so they broke easily, taking out the stator's winding and silicon steel plates at the same time. ${ }^{36}$ Generator malfunction was not the most common problem. According to the Ministry of Fuel Resources, $32.6 \%$ of all breakdowns across the nation in the first quarter of 1951 were caused by faulty transformers, $70 \%$ of these because of damage to the windings. Referencing Soviet performance benchmarks, the engineers noted that transformers operating at a normal temperature of $85^{\circ} \mathrm{C}$ had an expected shelf

35 Anon., "Zhongguo gongren de guangrong", p. 8.

36 Zhongyang ranliao gongyebu [Ministry of Fuel Resources]: Sulian dianye zhuanjia baogao dierji [Soviet electrical experts' report], Beijing: Ranliao gongyebu chubanshe 1951, p. 178-182. 
life of 20 to 25 years, but as the insulation wore off, the operating temperature increased to $150^{\circ} \mathrm{C}$, causing the transformer to burn out within a few years. ${ }^{37}$ Transformers with worn-out insulation were largely built during the War of Anti-Japanese Resistance, when both Japan and China faced material shortages.

The engineers lamented that workers carried out maintenance tasks without understanding fundamental principles and ended up damaging the equipment they wanted to maintain. In his speech during the safety inspection meeting in September 1950, Bao related an anecdote of a foreign technician who overfilled the oil in the steel bearings, causing the power station's water pump to break down. He filled the steel bearings with the best oil, but the oil deteriorated quickly and had to be replaced every two weeks. Upon further inspection, the engineers realised that the oil protected the bearings from corrosion but did not serve as a lubricant. Overfilling the bearings with oil increased friction, which led to excessive wear and tear. ${ }^{38}$ The mechanic at fault was purportedly a foreigner who had worked in the plant before 1949. The story reflected the realities of the electrical industries during the early Communist takeover. Bao's remarks were aimed at the ad-hoc inspection committees that covered up underlying problems rather than fully resolving them.

The engineers felt compelled to formalise maintenance protocols and eliminate systematic errors that caused catastrophic failure. As early as January 1951, Bao Guobao appointed an eight-person taskforce to compile a "Manual for Inspection and Repair of Electrical Equipment". Two of its members, Wang Pingyang and Yu En-ying, were among the first batch of engineers sent to the Tennessee Valley Authority for advanced training during World War Two. Wang specialised in high-voltage transmission lines and participated in the construction of the $154 \mathrm{kV}$ power line from the Apalachia Dam. Yu En-ying began his training in the design department but later branched out to focus on the "commercial and management side" of electrical power distribution. ${ }^{39}$ During their

37 Ibid, p. 180.

38 Bao, Guobao: “Anquan jiancha zhong ji ge ying zhuyi de wenti - jiu yue ershi ri zai anquan jiancha gongzuo huibao shang de jianghua [A few problems to take note of during safety inspections - speech at the safety inspection meeting on September 1950]", in: Renmin dianye 3 (Oct. 1950), p. 14-15.

39 Cheng, Yu-feng/Cheng, Yu-huang (eds.): Ziyuan weiyuanhui jishu renyuan fu mei shixi shiliao [Archives on the National Resources Commission Technicians' Training in the United States], Taipei: Academia Historica 1990, p. 122. The chapter in the "Maintenance Manual" on protecting the electrical grid from lightning strikes is largely based on the notes of Sun Yun-suan, a TVA trainee who was sent to Taiwan and 
advanced training at the TVA, Wang and Yu submitted monthly training reports to their supervisors at the National Resources Commission. These reports provided the raw material for the technical manual. Draft chapters were circulated in the bi-weekly Renmin dianye (People's Electrical Industries) journal. Engineers and technicians across the country were encouraged to share their experience and offer suggestions for revision. The engineers employed techniques of mass mobilisation to transform the compilation of the technical manual into a collective enterprise.

The engineers recognised maintenance lapses with generators and transformers as the most pressing problems and published these draft chapters first. The first chapter went straight to the underlying cause of generator burnouts and then spelled out instructions for the routine cleaning of the rotor and the stator. The manual specified that "The dust on the coils had to be blown with compressed air from 1.7 to $2.5 \mathrm{~kg} / \mathrm{cm}^{3}$, or removed with a vacuum cleaner then wiped off with a cotton cloth. The grease on the coil may be removed with carbon tetrachloride, but not too much, as the substance does not evaporate easily and can damage the insulation after getting absorbed into it". ${ }^{40}$ Overall, the manual adopted a comprehensive approach towards maintenance and repair. Every section adhered to a fixed format with an inspection checklist, maintenance procedures, diagnostic methods for common problems and a troubleshooting guide. There were also pictorial guides that showed readers diagrams of commonlyused tools and detailed every single step of the maintenance procedures. The publication of the technical manual also coincided with establishment of an incident reporting system by the Ministry of Fuel Resources. The magnitude of potential hazards became clear after the second National Electrical Power Conference in 1951. In his April 1951 report, Bao's deputy director Zhang Bin noted that seven regional power networks had identified a total of 95,500 problems but were only able to rectify $8.32 \%$ of them. ${ }^{41}$

The published sources offer no information on the effectiveness of the formalisation of maintenance practices. Power stations across China, including those in North China, continued to report high incidences of serious accidents. In

later rose through the ranks to become Taiwan's premier, published in this edited volume (p. 640-647).

40 Anon.: "Dianqi shebei jianxiu bixie [Draft of Handbook for the Maintenance of Electrical Facilities]", in: Renmin dianye 7 (Jun. 1951), p. 3-39. Quotation from p. 5.

41 Zhang, Bin: "Guanyu anquan gongdian he jishu bao'an gongzuo de jidian wenti [A few problems regarding the safe provision of electrical power and technical security]", in: Renmin dianye 7 (Jun. 1951), p. 1-8. 
the nine months of 1953, Qingdao Power Station in Shandong reported 20 outages, with 18 of them happening in the month of July. Lightning struck the transmission cables during the rainy season in summer. Since lightning arresters were in short supply, the power bureau did not install them on some of the transmission towers and was therefore unable to "avoid a power outage whenever there was a thunderstorm". ${ }^{42}$ Incident reports recognised the need for regular maintenance but acknowledged that there were lapses in quality control, so much so that it was "better to leave things unrepaired". ${ }^{43}$ The special issue on the "increase production, practise economy" campaign offered some clues about the electrical power industry exceeding quotas despite the high frequency of power outages. Of the seven reports, four of them detailed how power plant workers increased output by reducing fuel wastage during transportation and combustion. The only report that attributed increased output to stringent maintenance came from the Beijing Power Bureau. 120 power line workers from East China went to Beijing to certify the overhaul of Beijing's power network ahead of National Day in 1953. The remaining two articles were about power conservation efforts by the cotton mills in Shanghai and paper manufacturing in Shandong. Put simply, workflow improvements implemented by rank-and-file workers offered quick fixes that translated to observable results. Workers, not engineers, took credit for productivity gains.

\section{CONCLUSIONS}

Material scarcity during the War of Anti-Japanese Resistance (1937-1945) led to an involuntary transition from replacement to repair in China. The wartime economic blockade disrupted the supply of electrical parts to the country's fledgling electrical industry. The state-run power companies under the Nationalist regime in Southwest China were particularly hard hit. Their engineers and technicians accumulated considerable experience in repairing battle damage, as they dismantled electrical equipment from coastal cities and transported it over land, rehabilitating the power infrastructure of wartime Chongqing and Kunming after damaging air raids. Those who performed heroic repairs for the Nationalist regime during the War of Anti-Japanese Resistance defected to the Communists after

42 Zhong, Shufeng/Yu, Longhai: "Qingdao dianye ju guanli boru, shigu buduan fasheng [Weaknesses in technical management in the Qingdao Power Bureau; Accidents keep happening]", in: Renmin dianye 13 (Oct. 1953), p. 28.

43 Ibid. 
1949. Their expertise in repair and maintenance allowed the Communists to take over the electrical infrastructure with minimal disruption.

The workers' approach of tinkering with the workflow became more visible than the systems analyses performed by engineers, since it fit into the Communist Party's overall strategy of improving productivity through mass mobilisation. Elaborating on Lenin's formula "Communism is Soviet government plus the electrification of the whole country", Zhang Bin, head of the Electric Bureau in the Ministry of Fuel Resources, noted that "The transition towards communism requires the electrification of the whole country, as it requires the entire national economy to move towards large-scale production". ${ }^{44}$ Workflow adjustments aimed at improving the electrical industry's fuel efficiency involved the participation of many more workers than specialised maintenance tasks. Repair and maintenance became a means of imposing discipline on the vast industrial workforce.

During the first five-year plan (1953-1957), the electrical industry increased electricity supply not primarily through the addition of new generating capacity but by spreading power demand evenly throughout the day with the readjustment of production schedules. As a result, the maintenance of a safe and efficient power system became the collective responsibility of all workers. The expertise developed through decades of tinkering and repair under conditions of material scarcity would culminate in the November 1958 mass electrification campaign, during which the Ministry of Electrical Industries called on the entire population to build improvised power plants to relieve chronic power shortages following the launch of the Great Leap Forward.

44 Zhang, Bin: "Dianli gongye zai fazhan guomin jingji zhong de zuoyong [The role of electrification in the development of the national economy]", in: Renmin dianye 15 (Aug. 1955), p. 4. 